\title{
The Contribution of the GIS and the Principal Component Analysis in the Study of the Cement's Dusts Impact on the Top Soils in the Central Part of the Oujda-Taourirt Corridor (Eastern Morocco)
}

\author{
Mohamed El Kharmouz , Mohamed Sbaa, Sanae Saadi \\ Mohamed First University, East Center of the Water Sciences and Technologies, Oujda, Morocco \\ Email: ${ }^{*}$ m.elkharmouz@gmail.com
}

Received October 28, 2013; revised November 28, 2013; accepted December 4, 2013

Copyright (C) 2013 Mohamed El Kharmouz et al. This is an open access article distributed under the Creative Commons Attribution License, which permits unrestricted use, distribution, and reproduction in any medium, provided the original work is properly cited.

\begin{abstract}
Cement dust pollution is one of the sources of atmospheric pollution. The main impacts of the cement activity to the environment are the broadcasts of dusts and gases. The objective of this study is to determine the effects of cement dust pollution on physico-chemical characteristics of the soil at the vicinity of the cement factory in Oujda-Taourirt corridor (Eastern Morocco) using Principal component analysis (PCA) and geographical information system (GIS). Forty one (41) surface soils $(0-3 \mathrm{~cm})$ were collected from the six rural townships surrounding the cement factory. The collected soil samples were analyzed for their chemical properties $\left(\mathrm{CaO}, \mathrm{Al}_{2} \mathrm{O}_{3}, \mathrm{Fe}_{2} \mathrm{O}_{3}, \mathrm{~K}_{2} \mathrm{O}, \mathrm{MgO}, \mathrm{SO}_{3}\right.$ and $\left.\mathrm{SiO}_{2}\right)$ as well as their $\mathrm{pH}$ and Electric Conductivity. The results of the analysis showed that the dusts emitted by the cement plant are especially basic and contain a high free lime $(43.03 \% \mathrm{CaO})$. The principal component analysis applied on the 41 superficial soil samples, allows deducting that the free lime and the sulfur oxide are the tracer elements of this form of pollution. Furthermore, the spatial projection of the factor scores of the principal component analysis using the geographical information system permits us to determine the spatial distribution of more polluted areas of soils as well as to estimate their impact at a zone of $2.5 \mathrm{~km}$ of beam around the factory.
\end{abstract}

Keywords: Cement Dust; Soil; Spatial Distribution; Physico-Chemical Analysis; PCA

\section{Introduction}

The cement dust that produced by cement manufacturing process is considered as one of the most hazardous pollutants, which affects the surrounding environment. These dusts can be emitted at every stage of the manufacturing process of the cement: extraction of the raw material crusher, rotary kiln, cranes, mills, storage silos and packing sections, etc. [1]. The deposit of the cement particles is complex and it is controlled by the atmospheric stability, the roughness of the surfaces as well as the diameter of the particles [2]. These cement particles get deposited on top soil and vegetation as well as enter into the soil as dry, humid or occult deposits and can affect its physiochemical properties [3]. Certainly, the dry deposit of the atmospheric particles is a longer process than the two other types of deposits [4]. Indeed, it is relevant to men-

\footnotetext{
${ }^{*}$ Corresponding author.
}

tion that in the arid regions, the dry deposits are particularly more important [5]. The suspension particles emitted by the factories of cement lead to the modification of the receiving grounds properties. They increase their $\mathrm{pH}$ and salinity and also enrich them in metallic and mineral pollutants [6].

In eastern of Morocco, Holcim-Oujda cement factory is located in a rural area in the Oujda-Taourirt corridor and surrounded by seven rural districts whose residents are based their activities on agriculture. This cement factory emits annually enormous quantities of fine particles rich in ashes of coal and some free lime $(\mathrm{CaO})$, accompanied with some gases and oxides of nitrogen $\left(\mathrm{NO}_{\mathrm{x}}\right)$ [7].

The main objective of this research is to assess the impact of the dusts given out by a cement factory on the physicochemical characteristics of the soil at the vicinity of the Holcim-Oujda cement factory using Geographic 
information system and principal component analysis.

\section{Study Area}

The zone of survey is part of the corridor Oujda-Taourirt that is located in North-East of Morocco, (Figure 1). It situated in township Ain Lahjar that presents an arid climate [8] and geology to chalky dominance [9].

The winds in the corridor are constantly present, even low-speed and exercise considerable influences on vegetation and soil. Among these winds we distinguish: 1) The North winds which are of Mediterranean origin, wet and characterized by a very low speed. 2) The western winds which are of Atlantic origin and rainy. These winds dominate with $70 \%$ in the total average especially in winter and in spring. 3) The East and South winds which are of continental origin, these winds are hot and dry, especially in summer.

\section{Materials and Methods}

A total of 41 soil samples were collected from the six rural townships surrounding the cement factory (Figure 2). Tree soil samples were collected from inside of the factory, 13 soil samples were taken from township Ain Lahjar, 9 soil samples from township Rislane, Four samples were collected from each of the following township: Sidi Bouhouria, Bsara, Mestferki. 3 soil samples from Sidi Moussa Lamhaya and one sample from Ain Sfa District. The samples were most densely collected near the cement plant and became less densely collected with increasing distance from the cement plant. Bulk samples of $2 \mathrm{~kg}$ of top soil samples were collected within $0-3 \mathrm{~cm}$ depth. The soil samples were homogenized by coning and quartering, dried at $100^{\circ} \mathrm{C}-110^{\circ} \mathrm{C}$ oven during $24 \mathrm{~h}$ and then finely powdered and sieved to $2 \mathrm{~mm}$ and further crushed in the crusher mark Hezog for analysis [10].

The $\mathrm{pH}$ was determined with a glass electrode in a soil solution with a report soil/water equal to $1 / 2.5$ and electrical conductivity (EC) was determined with an electrical conductivity meter in a 1:5 soil/water suspension [11]. Mineralogical analysis (oxides of calcium, aluminum, iron, potassium, magnesium, sulphur and silica) of the soil samples were carried out by fluorescence through $\mathrm{X}$ rays [12].

To well present the spatial distribution around the factory of various measured parameters, Geographical information system (GIS) was used. The software surfer 8 permitted us to draw maps of isovalue. For identifying patterns in data and expressing the data in such a way as to highlight their similarities and differences, the principal component analysis (PCA) was used. PCA can provide information on the source contribution of particle composition. It was applied to quantify the source contribution [13]. Concentrations of mineralogical elements were compared using One-Way analysis of variance (ANOVA) to compute the statistical significance of the mean at various distances from the factory site. The difference for each element concentration was significant at $\mathrm{P}<0.05$ [14]. Statistical analyses (ANOVA) were performed with XLSTAT 2013 for windows.

\section{Results and Discussions}

The composition of cement dust is extremely variable and depends on the kiln type, cement type, source of the raw materials, and fuels being used [15]. Table 1 sum-

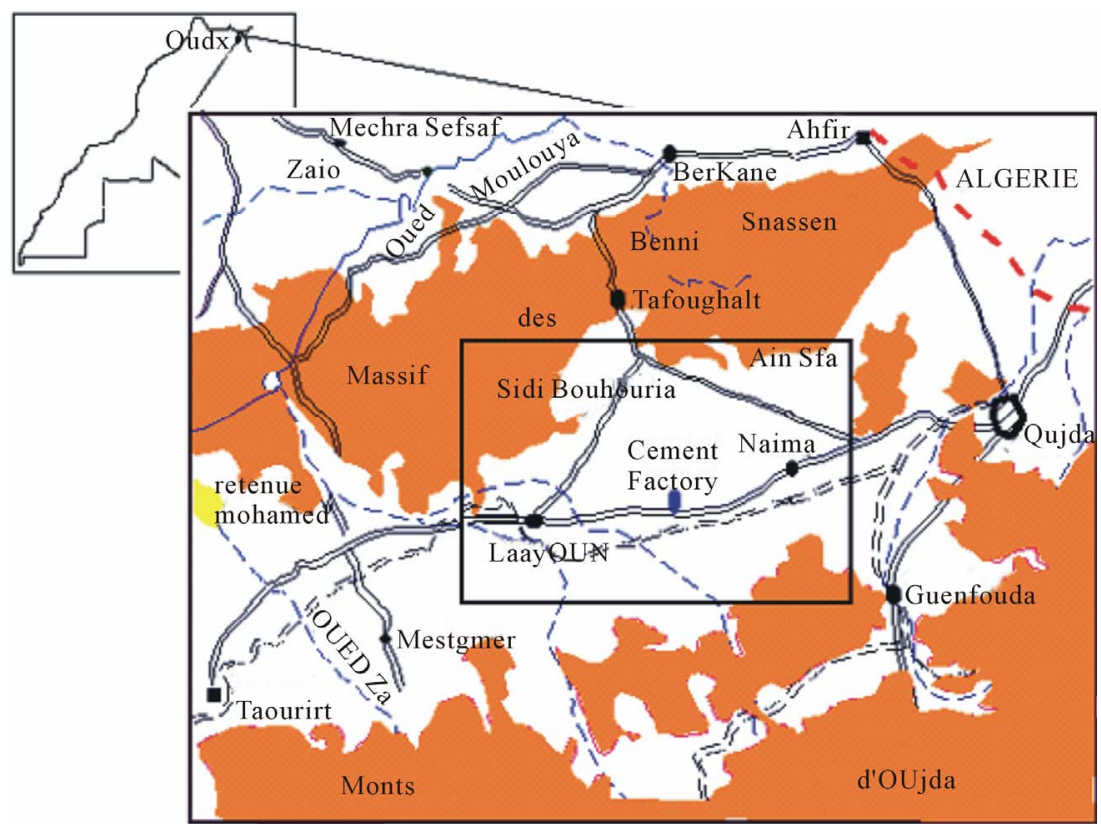

Figure 1. Location of the survey zone. 


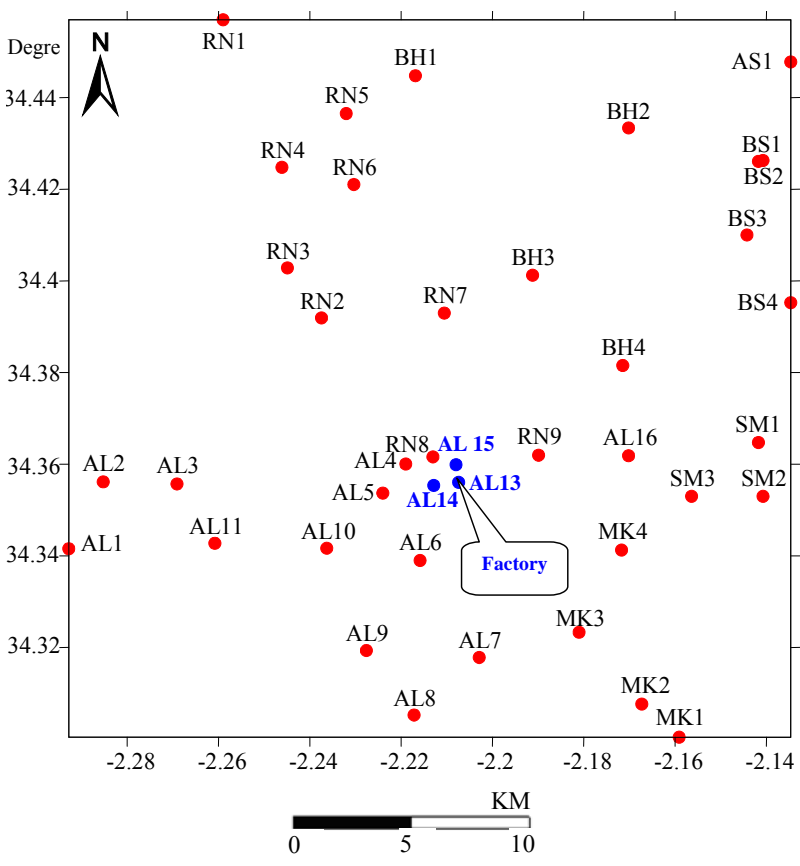

Figure 2. Position of sampling points at the vicinity of the cement factory (Soil samples collected inside the factory are labelled AL13, AL14 and AL15, and outside of the factory are labelled according to the initials of the townships names of sampling).

Table 1. Physico-chemical characteristics of the cement dusts and raw materials.

\begin{tabular}{cccc}
\hline & & \multicolumn{2}{c}{ Raw materials } \\
\cline { 3 - 4 } & Cement dusts & \multicolumn{2}{c}{ Limstone clay } \\
\cline { 3 - 4 } $\mathrm{pH}$ & & 9.68 & 7.81 \\
$\mathrm{EC}(\mu \mathrm{s} / \mathrm{cm})$ & 10.95 & 244 & 800 \\
$\mathrm{Cl}(\mathrm{ppm})$ & 2450.13 & 39.56 & 1235 \\
$\mathrm{CaO}(\%)$ & 43.03 & 49.67 & 10.343 \\
$\mathrm{SiO}_{2}(\%)$ & 10.46 & 4.74 & 48.44 \\
$\mathrm{Al}_{2} \mathrm{O}_{3}(\%)$ & 3.5 & 1.38 & 13.08 \\
$\mathrm{Fe}_{2} \mathrm{O}_{3}(\%)$ & 1.51 & 0.68 & 6.8 \\
$\mathrm{MgO}(\%)$ & 2.01 & 1.04 & 2.63 \\
$\mathrm{~K}_{2} \mathrm{O}(\%)$ & 1.04 & 0.51 & 2.93 \\
$\mathrm{SO}_{3}(\%)$ & 1.36 & 0.36 & 0.12 \\
\hline
\end{tabular}

marize the concentrations of chemical elements in cement dusts samples collected in the chimney of cement factory and raw materials samples collected in the extraction quarries of clay and limestone. The dusts have a very basic $\mathrm{pH}$ (10.95). Moreover, they are characterized by an elevated salinity $(710 \mu \mathrm{s} / \mathrm{cm})$, and they are rich in oxide of calcium (43.03\%) and chlorides (2450.13 ppm). On the other hand, they are poorer in the oxides of aluminium $\left(\mathrm{Al}_{2} \mathrm{O}_{3}\right)$, iron $\left(\mathrm{Fe}_{2} \mathrm{O}_{3}\right)$, potassium $\left(\mathrm{K}_{2} \mathrm{O}\right)$, magnesium $(\mathrm{MgO})$, sulfur $\left(\mathrm{SO}_{3}\right)$ and the silica $\left(\mathrm{SiO}_{2}\right)$. These results are similar to those found by Zerrouqi and et al., [6] in the same study area.

It is necessary to note that the content of the dust in
$\mathrm{SO}_{3}$ is superior to that of the raw materials. $\mathrm{High} \mathrm{SO}_{3}$ content in cement dusts is due to removal of sulphur by alkaline materials [16].

To assessing the impact of dusts emitted by the factory on the characteristics of neighbouring top soils, we considered useful to follow the spatial variation of $\mathrm{pH}$ and conductivity of soils as well as their content in chlorides, particularly $\mathrm{CaO}$ and $\mathrm{SO}_{3}$ using geographical information system (GIS) and principal component analysis (ACP).

The first principal component has a variance (Eigen value) of 4.304 and is $61.48 \%$ of the total variance (Table 2), the second principal component has a variance of 1.205 and is $17.22 \%$ of the variability of data, the third principal component has a variance (value own) of 0.807 and is $11.541 \%$ of the total variance. The first three factors account for $90.25 \%$ of total inertia.

The chemical elements were separately planned in the factorial plan F1 $\times$ F2. We will limit our observation projection variables and samples in the circle formed by the axes $\mathrm{F} 1$ and $\mathrm{F} 2$, since they present a significant threshold superior to $15 \%$. The inertia of these two factors is of $78.70 \%$, at the rate of $61.48 \%$ for the F1 axis and $17.22 \%$ for the F2 axis. Figure 3 showed that PCA differentiated three groups of which each one represents an assembly of chemical elements that characterizes the issuing source:

1) Group one stands on the negative plan of the $F 1$ and F2 axis, is represented by the characteristic elements of soil $\mathrm{Al}_{2} \mathrm{O}_{3}, \mathrm{Fe}_{2} \mathrm{O}_{3}, \mathrm{~K}_{2} \mathrm{O}$ and $\mathrm{MgO}$.

2) Group two stands on the negative pole of the $F 1$ and on the positive plan of F2 axis, opposing the first group. It is represented by silica $\left(\mathrm{SiO}_{2}\right)$. This is represented by RN1, RN5, RN7, BH2 and SM1. These samples have a clayey origin.

3) Group three stands on the positive plan of the F1

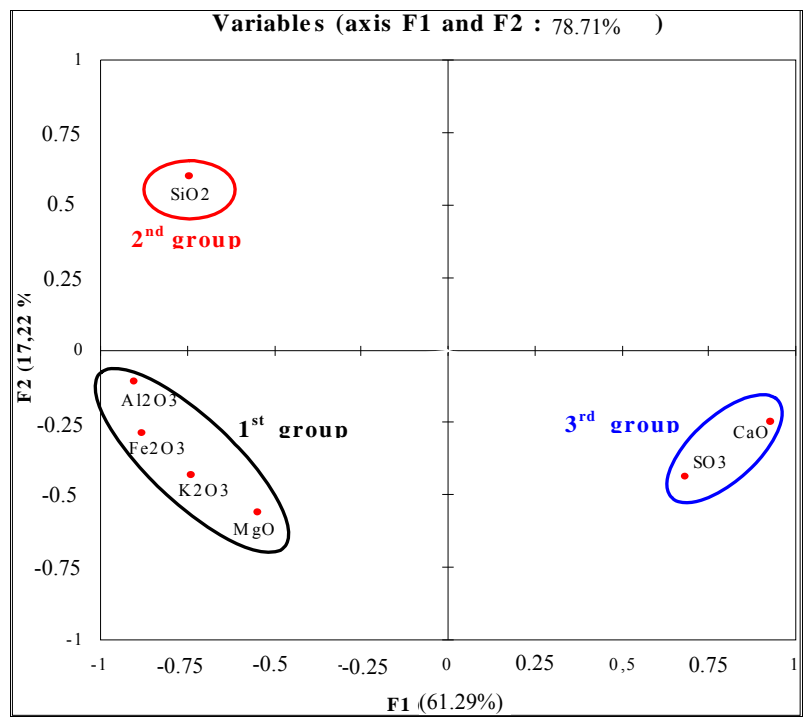

Figure 3. Projection of the variables (chemical compounds) on the plan factorial F1 $\times$ F2. 
Table 2. Initial eigen values and variance of factors.

\begin{tabular}{cccccccc}
\hline & F1 & F2 & F3 & F4 & F5 & F6 & F7 \\
\hline Raw Value & 4.304 & 1.205 & 0.807 & 0.428 & 0.153 & 0.08 & 0.02 \\
\% Variance & 61.489 & 17.22 & 11.541 & 6.1146 & 2.191 & 1.143 & 0.299 \\
\% Cumulated & 61.489 & 17.22 & 90.25 & 96.365 & 98.557 & 99.7 & 100.00 \\
\hline
\end{tabular}

and on the negative plan of $\mathrm{F} 2$ axis. It is formed by the two elements $\mathrm{SO}_{3}$ and $\mathrm{CaO}$, which are two main indicators of the pollution induced by the cement industry. This is represented by AL15 sample collected inside the factory and by MK2, MK4, RN9, AL2 and AL16 samples (Figure 4).

The F1 axis indicates the influence of local anthropogenic activities on soil samples; it opposes the $1^{\text {st }}$ and $2^{\text {nd }}$ groups to the $3^{\text {rd }}$ group. To this axis contribute the elements $\mathrm{Al}_{2} \mathrm{O}_{3}, \mathrm{Fe}_{2} \mathrm{O}_{3}, \mathrm{~K}_{2} \mathrm{O}$, negatively $\mathrm{MgO}$ and $\mathrm{CaO}, \mathrm{SO}_{3}$ positively. The $\mathrm{F} 2$ axis is defined by the second group of the $\mathrm{SiO}_{2}$ that opposes to the first group.

The spatial distribution of F1 factor which is achieved with the help of the geographical information system permits to determine the area impact of the cement factory The spatial distribution of this factor (dust pollution axis) (Figure 5) shows that the positive values of this factor $\left(\mathrm{CaO}\right.$ and $\left.\mathrm{SO}_{3}\right)$ are concentrated inside the factory (AL15, AL13) and in its immediate neighbourhood, until $2.5 \mathrm{~km}$ far from the factory, particularly in the direction of west. The positive values are also observed in the soil samples resulting from de Ain lahjar and Rislane Township, because these soils have a calcareous origin. A strong concentration in $\mathrm{CaO}$ is also noted in $\mathrm{BS} 3$ sample which is collected in the neighbourhood of a career deprived for the extraction of building materials. These results are similar at those obtained by statistical analysis one-way ANOVA. Indeed, ANOVA at $\mathrm{P}<0.05$ showed that the differences observed between all chemical elements at various distances from the factory are significant, except $\mathrm{Fe}_{2} \mathrm{O}_{3}$ at $5 \mathrm{~km}, \mathrm{AL}_{2} \mathrm{O}_{3}$ at $10 \mathrm{~km}$ and $\mathrm{CaO}$ at $15 \mathrm{~km}$ (Table 3 ). Generally at $2.5 \mathrm{~km}$ far from the factory, the differences are highly significant.

The $\mathrm{CaO}$ spatial distribution is similar to that of the $\mathrm{SO}_{3}$ (Figures 6 and 7). $\mathrm{CaO}$ values ranged from 6.98\% to $39.19 \%$. The $\mathrm{SO}_{3}$ was low in soil samples and they ranged from $0.14 \%$ to $1.57 \%$. The $\mathrm{CaO}$ and $\mathrm{SO}_{3}$ distributions showed that the highest values were observed inside the factory, notably AL13 and AL15 and beside the careers clay (AL16). Such results were stood in agreement with the results reported by Zerrouqi and et al., [6]. $\mathrm{CaO}$ and $\mathrm{SO}_{3}$ Pollutants propagate around the factory and the limestone quarry at a distance approximately of $2.5 \mathrm{~km}$, especially in the direction of west. Indeed, the factory is situated in Oujda-Taourirt Corridor oriented East-West. Prevailing wind in this corridor are East winds which are of continental origin, these winds are hot and dry, especially in summer. In AL8, MK1, MK2, BS3 and AS1 soil samples, the $\mathrm{CaO}$ values exceed $17 \%$, because the soil of these regions is calcareous.

The relationships between pollutant elements can provide important information on their sources [17]. In this study, a significant correlation $(\mathrm{R}=0.656)$ are found among $\mathrm{CaO}$ and $\mathrm{SO}_{3}$, suggesting that these pollutants may originate from a common pollution source (cement dusts). Taylor, [18] showed that the free lime $(\mathrm{CaO})$ are formed in cement dust when limestone is heated during cement manufacturing. However, the $\mathrm{CaO}$ may change to $\mathrm{CaOH}$ and then to $\mathrm{CaCO}_{3}$ the longer the dusts are in equilibrium with the atmosphere.

The sulfur oxide in soil can have an organic or mineral origin. The accumulation of $\mathrm{SO}_{3}$ in the dust deposit collected inside the factory confirms the entropic origin of the elevation of the percentages of this element in soils inside the factory and those of its immediate neighbourhood. Karbassi and et al., [16] showed that de $\mathrm{High}_{\mathrm{SO}_{3}}$ content in cement factories is due to removal of sulfur by alkaline materials. It is important to underline that the $\mathrm{SO}_{3}$ present in soil can have another entropic origin, which is the combustion of the fossil fuels (coke of oil) used by the factory and which generates the $\mathrm{SO}_{2}$ [19].

The isovalue map of the $\mathrm{pH}$ created by the Surfer 8 software (Figure 8) showed that the soil $\mathrm{pH}$ for all the samples was found greater than 8 which indicated that the soils are alkaline. It averaged between 8.13 and 9.08. The isovalue map showed also 4 main pits:

1) The first is noted inside and in immediate neighbourhood of the factory. It includes the AL13, AL15 and AL14 points. The elevation of the $\mathrm{pH}$ in these zones can be linked easily to an important deposit of the cement dusts in these zones. The change of $\mathrm{pH}$ in soils to alkaline range is mostly caused by the dominant component of cement dust calcium carbonate [20].

2) The second pit, which is less important, is recorded to immediate neighbourhood of limestone quarry.

3) The third and fourth pits, in AL10 and AL7 samples respectively. The $\mathrm{pH}$ values upper to 8.8 propagate in the East direction towards Mestferki township and in the West direction towards Ain Lahjar township. Indeed, the soils of these tow township is calcareous. They are rich in calcite $\left(\mathrm{CaCO}_{3}\right)$ and dolomite $(\mathrm{CaMg}) \mathrm{CO}_{3}$ [21]. This rise of the $\mathrm{pH}$ can have fatal effects on the vegetation. As 


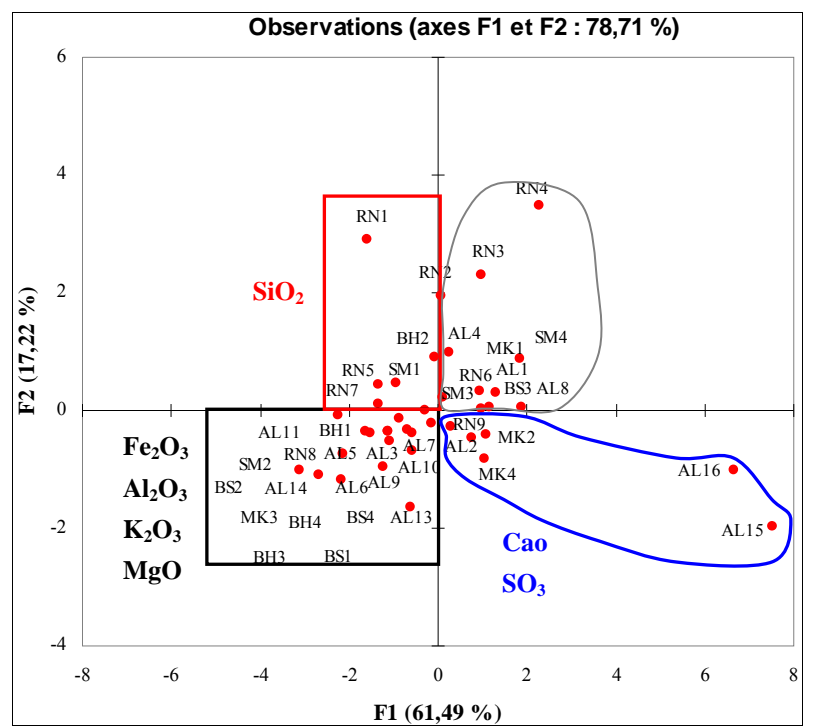

Figure 4. Projection of the sample soil variables on the plan factorial F1 × F2.

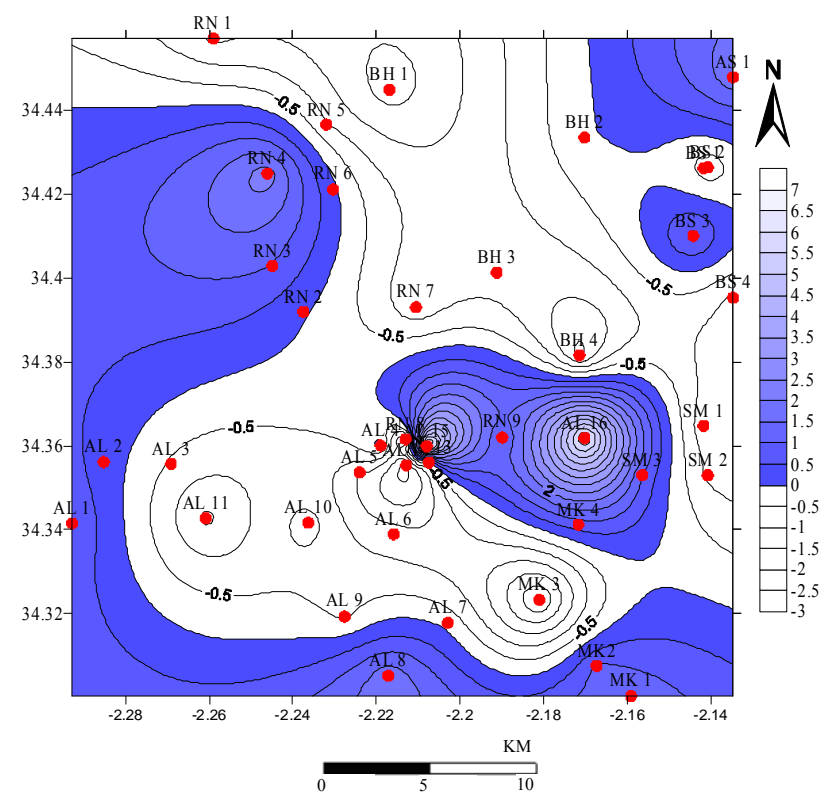

Figure 5. Spatial distribution of the score's samples regarding the F1 factor.

the soil $\mathrm{pH}$ increases, the solubility of many nutrients is reduced. As a result, these nutrients are precipitated as solid materials that plants cannot use [22].

Generally, the highest values of $\mathrm{pH}$ have soil samples taken from the closest neighborhood of the cement plant, and the lowest in the outermost soils. Similar relation between soil $\mathrm{pH}$ and the distance from the cement plant was observed by other authors $[20,23]$.

The electric conductivity values of the soil samples vary between 78.25 and $784 \mu \mathrm{s} / \mathrm{cm}$ (Figure 9). These values which are lower than $800 \mu \mathrm{s} / \mathrm{cm}$ testify that these soils are low in salinity $(<0.25 \mathrm{mS} / \mathrm{cm})$ to moderate $(0.25$

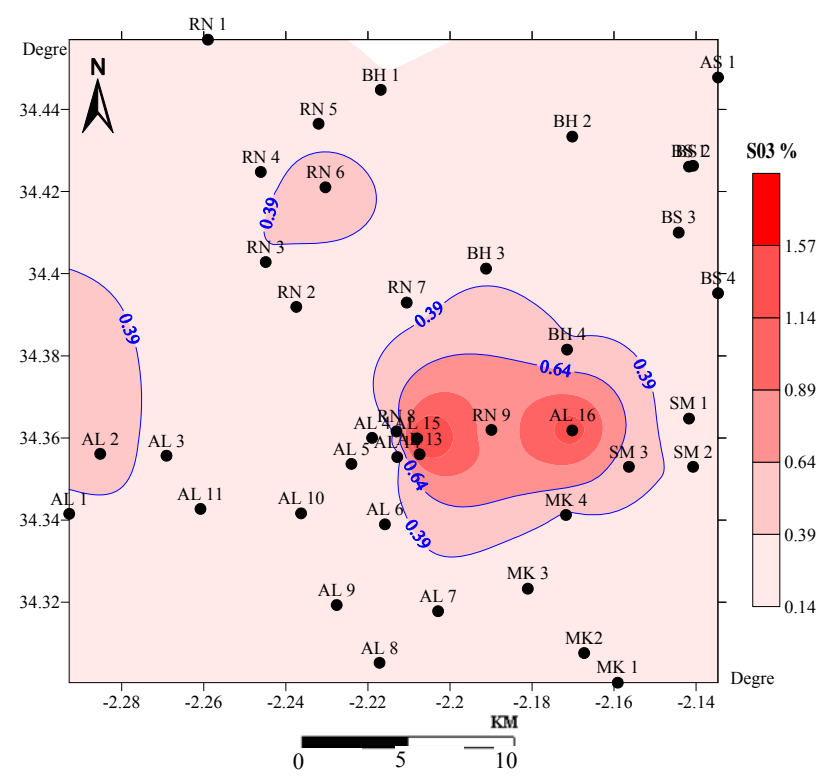

Figure 6. Spatial distribution of $\mathrm{SO}_{3}$ percentage in soil.

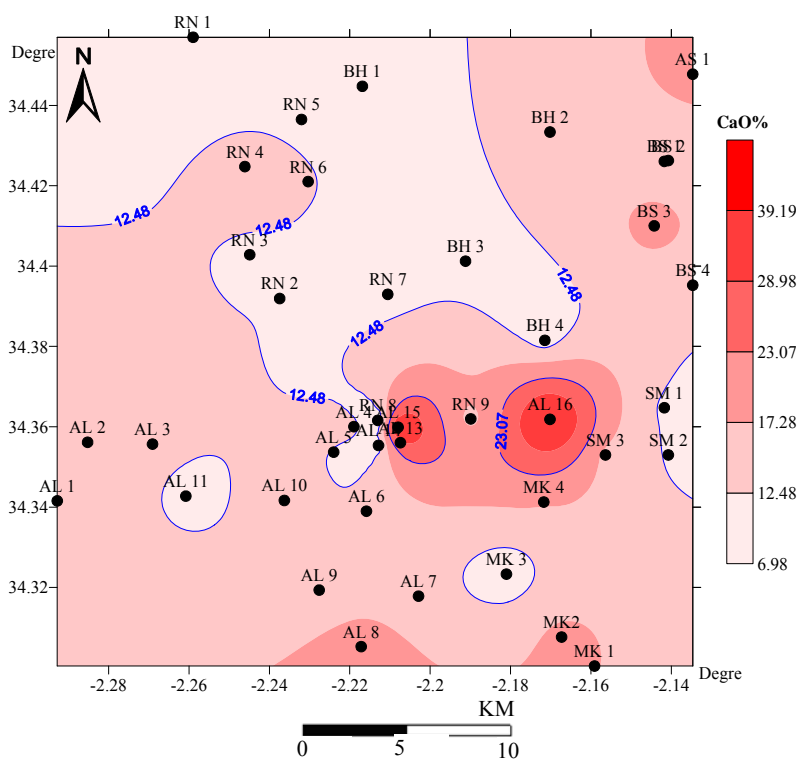

Figure 7. Spatial distribution of $\mathrm{CaO}$ percentage in soil.

and $0.8 \mathrm{mS} / \mathrm{cm}$ ) [22]. The upper values were registered inside the factory and in agricultural soils of Rislane township. Inside the factory and in its neighbourhood (until $2.5 \mathrm{~km}$ surrounding the plant), the elevation of EC is attributed at a strong content of chlorides in cement dusts (2450.13 ppm). In the soils collected from Rislane, the elevation of EC may be result of massive use of fertilizers in agriculture.

\section{Conclusion}

The data obtained with PCA in this study allow us to deduct that $\mathrm{CaO}$ and $\mathrm{SO}_{3}$ are the element tracers of the pollution led by the cement industry. It also permitted us 
Table 3. Soil parameters and the variance analysis in relation to distance from the factory.

\begin{tabular}{|c|c|c|c|c|c|c|c|c|}
\hline Distance (km) & & $\mathrm{SiO}_{2}$ & $\mathbf{A l}_{2} \mathbf{O}_{3}$ & $\mathrm{Fe}_{2} \mathrm{O}_{3}$ & $\mathrm{CaO}$ & MgO & $\mathrm{SO}_{3}$ & $\mathbf{K}_{2} \mathbf{O}_{3}$ \\
\hline & Mean & 43.07 & 8.78 & 3.31 & 28.96 & 2.26 & 0.28 & 1.82 \\
\hline \multirow[t]{3}{*}{$\mathbf{0}$} & Variance & 69.57 & 29.49 & 3.90 & 255.39 & 0.52 & 0.08 & 0.73 \\
\hline & $P$ & $3.80 \mathrm{E}-11$ & 0.048 & 0.043 & 0.034 & 0.0056 & 0.006 & 0.021 \\
\hline & Mean & 46.47 & 11.20 & 4.82 & 10.48 & 2.66 & 0.30 & 2.52 \\
\hline \multirow[t]{3}{*}{1} & Variance & 6.27 & 3.08 & 0.39 & 10.52 & 0.038 & 0.01 & 0.12 \\
\hline & $P$ & 2.91E-08 & $2.43 \mathrm{E}-5$ & $1.91 \mathrm{E}-5$ & 0.0011 & $2.75 \mathrm{E}-6$ & $9.41 \mathrm{E}-6$ & $1.45 \mathrm{E}-4$ \\
\hline & Mean & 42.28 & 11.40 & 4.25 & 14.27 & 2.77 & 0.36 & 2.19 \\
\hline \multirow[t]{3}{*}{2.5} & Variance & 18 & 1.81 & 0.10 & 5.35 & 0.07 & 0.03 & 0.04 \\
\hline & $P$ & $1.11 \mathrm{E}-11$ & $6.76 \mathrm{E}-10$ & $1.18 \mathrm{E}-7$ & $2.05 \mathrm{E}-7$ & 0.019 & $1.7 \mathrm{E}-12$ & 0.0019 \\
\hline & Mean & 45.92 & 12.09 & 4.29 & 13.17 & 2.84 & 0.22 & 2.23 \\
\hline \multirow[t]{3}{*}{5} & Variance & 30.20 & 4.04 & 0.93 & 11.47 & 0.22 & 0.007 & 0.08 \\
\hline & $P$ & $5.26 \mathrm{E}-9$ & $5.99 \mathrm{E}-6$ & 0.105 & $1.49 \mathrm{E}-4$ & $5.66 \mathrm{E}-7$ & 0 & $4.94 \mathrm{E}-10$ \\
\hline & Mean & 42.16 & 10.40 & 3.87 & 15.37 & 2.54 & 0.29 & 1.95 \\
\hline \multirow[t]{3}{*}{10} & Variance & 38.77 & 3.22 & 0.34 & 12.22 & 0.13 & 0.008 & 0.08 \\
\hline & $P$ & $1.12 \mathrm{E}-8$ & 0.56 & $2.5 \mathrm{E}-12$ & 0.0015 & $2.9 \mathrm{E}-13$ & 0 & 0 \\
\hline & Mean & 43.27 & 10.27 & 3.84 & 13.46 & 3.07 & 0.43 & 1.98 \\
\hline \multirow[t]{3}{*}{15} & Variance & 95.98 & 5.67 & 0.63 & 4.65 & 1.65 & 0.019 & 0.58 \\
\hline & $P$ & $6.05 \mathrm{E}-6$ & $2.02 \mathrm{E}-4$ & $9.7 \mathrm{E}-14$ & 0.083 & $6.2 \mathrm{E}-10$ & 0 & $9.76 \mathrm{E}-15$ \\
\hline & Mean & 46.45 & 12.66 & 4.38 & 12.88 & 2.46 & 0.20 & 2.02 \\
\hline \multirow[t]{2}{*}{20} & Variance & 55.50 & 3.69 & 0.51 & 14.13 & 0.11 & 0.002 & 0.07 \\
\hline & $P$ & $7.01 \mathrm{E}-7$ & $3.21 \mathrm{E}-7$ & $4.4 \mathrm{E}-16$ & $3.4 \mathrm{E}-04$ & 0 & 0 & 0 \\
\hline
\end{tabular}

At the 0.05 level the means are significatively different, except $\mathrm{Fe}_{2} \mathrm{O}_{3}$ at $5 \mathrm{kM}, \mathrm{Al} 2 \mathrm{O} 3$ at $10 \mathrm{~km}$ and $\mathrm{CaO}$ at $15 \mathrm{~km}$.

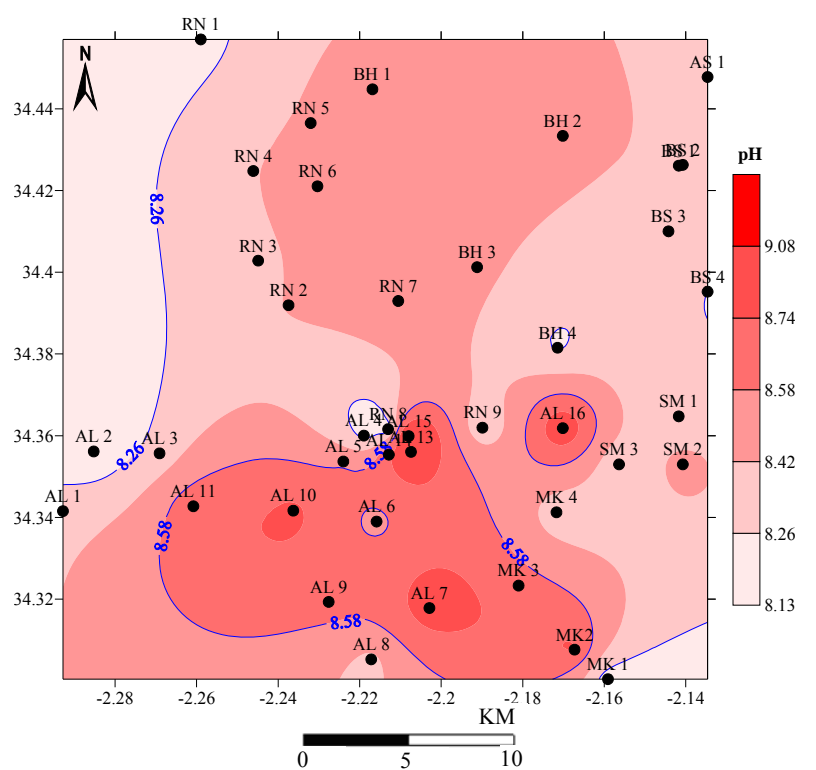

Figure 8. Spatial distribution of PH.

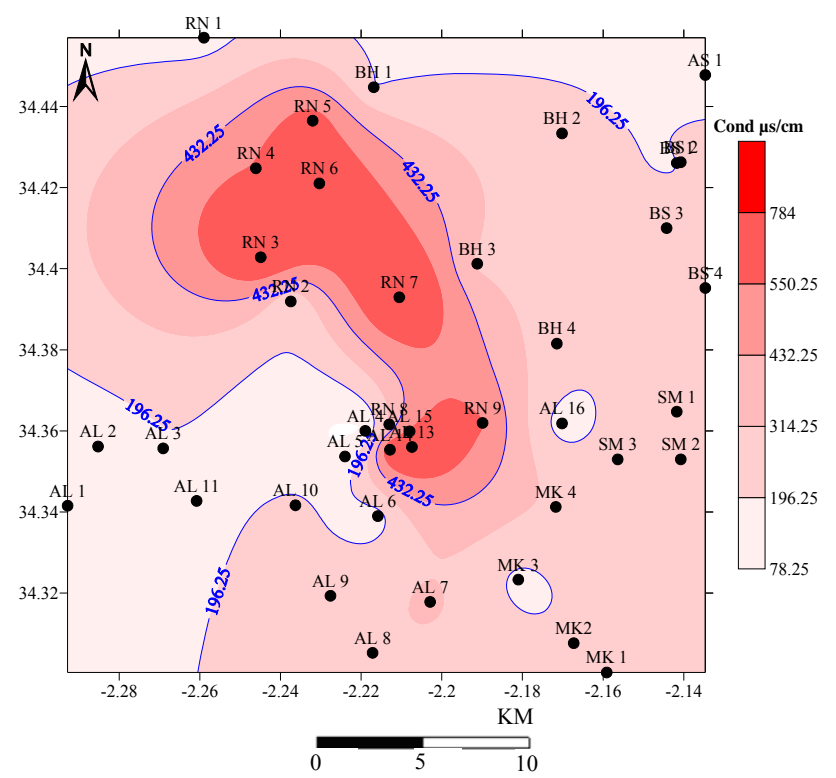

Figure 9. Spatial distribution of EC. 
to detect the soil samples affected by the particular pollution. The use of the geographical information system is allowed to value the spatial distribution of the polluting particles to the level of soil and to determine the surface impacted by the dust deposit which is estimated to a zone of $2.5 \mathrm{~km}$ of beam around the factory.

\section{REFERENCES}

[1] D. N. Huntzinger and T. D. Eatmon, "A Life-Cycle Assessment of Portland Cement Manufacturing: Comparing the Traditional Process with Alternative Technologies," Journal of Cleaner Production, Vol. 17, No. 4, 2008, pp. 668-675. http://dx.doi.org/10.1016/j.jclepro.2008.04.007

[2] J. R. Hosker and S. E. Lindberg, "Review: Atmospheric Deposition and Plant Assimilation of Gases and Particles," Atmospheric Environment, Vol. 16, No. 5, 1982, pp. 889-910.

http://dx.doi.org/10.1016/0004-6981(82)90175-5

[3] S. Gupta and S. Sharma, "Compound Effect of Cement Dust Emitted by Closely Located Cement Plants on Soil of Nokha (Bikaner)," Oriental Journal of Chemistry, Vol. 28, No. 4, 2012, pp. 1919-1925. http://dx.doi.org/10.13005/ojc/280454

[4] B. B. Hicks, "Differences in Wet and Dry Particle Deposition Parameters between North America and Europe," In: S. D. Lee, T. Schneider, L. D. Grant and P. J. Verkerk, Eds., Aerosols: Research, Risk Assessment, and Control Strategies, Proceeding of the Second US-Dutch Symposium, Williamsburg VA, Chelsea, May 1985, Lewis Publishers, pp. 973-982.

[5] D. A. Grantz, J. H. B. Garner and D. W. Johnson, "Ecological Effects of Particulate Matter," Environment International, Vol. 29, No. 2-3, 2003, pp. 213-239. http://dx.doi.org/10.1016/S0160-4120(02)00181-2

[6] Z. Zerrouqi, M. Sbaa, M. Oujidi, M. Elkharmouz, S. Bengamra and A. Zerrouqi, “Assessment of Cement's Dust Impact on the Soil Using Principal Component Analysis and GIS," International Journal of Environmental Science and Technology, Vol. 5, No. 1, 2008, pp. 125-134. http://dx.doi.org/10.1007/BF03326005

[7] M. El kharmouz, "Etude de L'Impact des Matières en Suspension Emises pas une Industrie Cimentière sur les Composantes du Milieu Récepteur: Eau, Plante et sol," Mémoire de DESA, Université Mohammed Premier, 2003, $208 \mathrm{p}$.

[8] B. Haloui, "La Végétation du Maroc Oriental, Phytoécologie, Phytomasse, Minéralomasse et Productivité des Principaux Ecosystèmes," Doctoral Thesis, Med First University, Oujda, 1991.

[9] A. Laouina, "Le Maroc Nord Oriental, Reliefs, Modelés et Dynamique de Calcaire," Mohammed First University Press, Oujda, 1990.

[10] H. M. Selim, M. C. Amacher and I. K. Iskandar, "Modelling the Transport of Chromium (VI) in Soil Columns," Soil Science Society of America Journal, Vol. 53, No. 4, 1989, pp. 996-1004. http://dx.doi.org/10.2136/sssaj1989.03615995005300040 $\underline{002 x}$
[11] S. J. Kotto, D. Bitom and B. Volkoff, "Matière Organique et Transformation Structurales Superficielles Dans un sol Ferralitique Rouge de la Zone Forestière du Cameroun," National Research Council (US). Committee on Tropical Soils, Vol. 25, No. 3, 1990, pp. 231-241.

[12] S. Janhäll, P. Molnár and M. Hallquist, "Vertical Distribution of Air Pollutants at the Gustavii Cathedral in Göteborg, Sweden," Atmospheric Environment, Vol. 37, No. 2, 2003, pp. 209-217. http://dx.doi.org/10.1016/S1352-2310(02)00858-0

[13] A. Arditsoglou and C. Samara, "Levels of Total Suspended Particulate Matte Rand Major Trace Elements in Kosovo: A Source Identification and Apportionment Study," Chemosphere, Vol. 59, No. 5, 2005, pp. 669-678. http://dx.doi.org/10.1016/j.chemosphere.2004.10.056

[14] T. B. Chen, J. W. C. Wong, H. Y. Zhou and M. H. Wong, "Assessment of Trace Metal Distribution and Contamination in Surface Soils in Hong Kong," Environmental Pollution, Vol. 96, No. 1, 1997, pp. 61-68. http://dx.doi.org/10.1016/S0269-7491(97)00003-1

[15] H. B. Van Oss and A.C. Padovani, "Cement Manufacture and the Environment Part 2: Environmental Challenges and Opportunities," Journal of Industrial Ecology, Vol. 7, No. 1, 2003, pp. 93-126. http://dx.doi.org/10.1162/108819803766729212

[16] A. R. Karbassi, H. R. Jafari, A. R. Yavari, H. Hoveidi and H. Sid Kalal, "Reduction of Environmental Pollution through Optimization of Energy Use in Cement Industries," Int. J. Environ. Sci. Tech., Vol. 7, No. 1, 2010, pp. 127-134. http://dx.doi.org/10.1007/BF03326124

[17] D. S. Manta, M. Angelone, A. Bellanca, R. Neri and M. Sprovieri, "Heavy Metals in Urban Soils: A Case Study from the City of Palermo (Sicily), Italy," The Science of the Total Environment, Vol. 300, No. 1-3, 2002, pp. 229243. http://dx.doi.org/10.1016/S0048-9697(02)00273-5

[18] H. F. W. Taylor, "Cement Chemistry," 2nd Edition, Thomas Telford, London, 1997. http://dx.doi.org/10.1680/cc.25929

[19] M. S. Reddy and C. Venkataraman, "Inventory of Aerosol and Sulphur Dioxide Emissions from India: I-Fossil Fuel Combustion," Atmospheric Environment, Vol. 36, No. 4, 2002, pp. 677-697. http://dx.doi.org/10.1016/S1352-2310(01)00463-0

[20] H. Jaworska and H. Dabkowska-naskrêt, "Total Content of Mercury in the Soils of the Surroundings of LafargeCement Plant in Malogoszcz," Ecological Chemistry and Engineering, Vol. 18, No. 9-10, 2011, pp. 1245-1250.

[21] S. Bengamra, M. Oujidi, J. Bastida and V. Esteve, "Apport de la Diffraction des Rayons X à la Détermination des traceurs minéralogiques de la Pollution Atmosphérique Particulaire D'Une Cimenterie," Pollution Atmosphérique, Vol. 192, No. 192, 2006, pp. 455-465.

[22] G. M. Zaiad, "Physico-Chemical Analysis of Soils in AlKhums City, Libya," Journal of Applied Sciences Research, Vol. 6, No. 8, 2010, pp. 1040-1044.

[23] A. Khamparia, S. K. Chattergee and G. D. Sharma, "Assessment on Effect of Cement Dust Pollution on Soil Health," Journal of Environmental Research and Development, Vol. 7, No. 1A, 2012, pp. 368-374. 